\title{
Distribution of syphilitic antibodies in gel-filtered serum fractions
}

\author{
ALAd ÁR JOBBÁGY \\ Hungarian State Institut of Dermatology and Venereology, Budapest
}

Sera from patients with primary syphilis have been fractionated by numerous investigators in order to explore the serological reactivity of the various classes of immunoglobulin. The methods applied have been the following:

Electrophoresis (Laurell, 1955; Laurell and Lindau, 1958; Portnoy, Julian, Smith and Harris, 1963);

Density gradient ultracentrifugation (Aho, 1967; Davis, Moore, Kabat, and Harris, 1945);

DEAE cellulose column chromatography (Laurell and Malmquist, 1961);

Gel filtration on Sephadex G 200 column (Aho, 1967; Julian, Logan, and Norins, 1969; Király and Jobbágy, 1969).

In the present work sera from patients with primary syphilis were gel-filtered and distributed into ten fractions in order to obtain detailed resolution. All active serum fractions were tested with the rapid plasma reagin (RPR) test, complement-fixation reactions with cardiolipin antigen (Card. C'FR) and $T$. reiteri protein antigen (RPC'FR), the fluorescent treponemal antibody (FTA) test, the fluorescent treponemal antibody test with sera absorbed by $T$. reiteri suspension (FTA-ABS), and the $T$. pallidum immobilization (TPI) test in order to examine the serological reactivity of immunoglobulin classes Ig $M$ and $\mathrm{Ig} \mathrm{G}$ in the presence of heat-labile interfering substances.

It is well known that, of the various serological reactions, the TPI is the last to become positive. Thus TPI non-reactive sera were regarded as representating a shorter duration of infection than TPI reactive sera. The aim was to obtain information about the sequence of antibody formation in humans by examining the serological reactivity of the different classes of immunoglobulin.

In addition, sera from three patients were fractionated after treatment of syphilis to ascertain the sequence in which the serological reactions of the immunoglobulin classes reversed to negative.

\section{Material and methods}

Six sera from patients with primary syphilis reactive to the STS were tested. The patients, who were all males, had inguinal adenopathy, and darkfield examinations for $T$. pallidum were positive. Sera from three (Cases 3, 4, and 5) were negative in the TPI test and the other three (Cases 1,2, and 6) were positive. Two non-syphilitic control sera, which were non-reactive (except to the FTA test), were examined in parallel (Controls 1 and 2).

Sera from three patients (Cases 1, 2, and 3) were also examined after 3,6 , and 9 months from the beginning of antisyphilitic treatment with 15 mega units Retardillin given for 15 to 18 days, the course being repeated after 4 weeks.

\section{(1) Gel filtration of sera}

2-ml. specimens of serum were subjected to gel filtration on a $2.55 \times 38.4 \mathrm{~cm}$. Sephadex G 200 column $\left(\mathrm{V}_{\mathrm{t}}=196 \mathrm{ml}\right.$.; $\mathrm{V}_{\mathrm{o}}=48 \mathrm{ml}$.). Protein was eluted at a rate of $22.5 \mathrm{ml}$./hr with TRIS buffer $(0.05 \mathrm{M}, \mathrm{ph}: 8)$, containing $1 \mathrm{M}$ sodium chloride. Elutes were collected in 3-ml. portions and absorbance was measured at $280 \mathrm{~nm}$. wave-length. The aliquots were collected and distributed into ten fractions. They were then dialysed and their protein content measured by Lowry's method. After $400 \mu \mathrm{g}$. streptomycin and $20 \mathrm{mg}$. gelatine had been added to each of them, the fractions were freeze-dried.

\section{(2) Immune electrophoretic analysis of fractions}

A 3- $\mu$ l. quantity of the fractions was electrophoretically separated in Michaelis buffer $(\mu=0.05 ; \mathrm{pH}: 8.6)$ at $65 \mathrm{~V}$ (Scheidegger, 1955). Precipitation lines developed with antihuman rabbit sera specific to Ig A, Ig G, and Ig M respectively (Hyland).

\section{(3) Serological examination of serum fractions}

Serum fractions were examined quantitatively. Dilutions giving 50 per cent. reactivity were conventionally accepted as the end-point of titrations. Serological tests were carried out according to the following methods:

Rapid plasma reagin test (Portnoy and Garson, 1960).

Complement-fixation reactions with cardiolipin antigen (Király, 1959) and with $T$. reiteri protein antigen (Király, 1968).

Indirect fluorescent treponemal antibody test (Király, Jobbágy, and Mecher, 1965) and fluorescent treponemal 
antibody test with sera absorbed by $T$. reiteri suspension (Király and Kováts, 1967).

T. pallidum immobilization test (Király and Károlyi, 1956).

\section{Results}

(1) Distribution of immunoglobulins in fractions of gelfiltered serum

Fractions were analysed by means of immune electrophoresis. The Ig $\mathrm{M}$ immunoglobulins were located in Fractions 1 and 2, the Ig G in Fractions 3 to 8, and the Ig $A$ in Fractions 3 to 5 (Fig. 1).

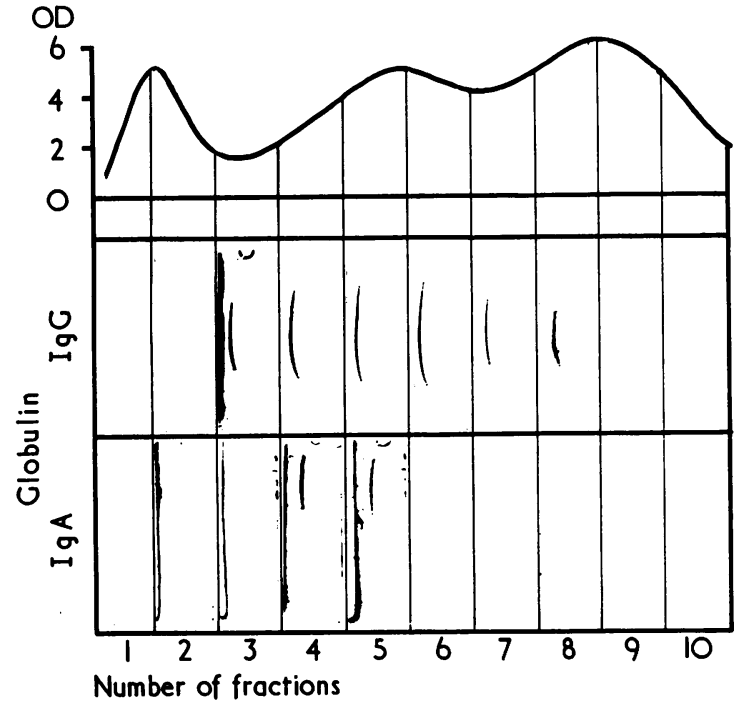

FIG. 1 Distribution of $\operatorname{Ig} A$ and $\operatorname{Ig} G$ immunoglobulins in gel-filtered serum fractions

Disregarding the small amount of Ig A, gel filtration may be used as a convenient and simple method for approximate separation of the Ig $G$ and Ig $M$ classes.
(2) Serological findings

The results are summarized in the Table. Before treatment RPR was positive in five, Card.C'FR in five, RPC'FR in six, FTA-50 in six, FTA-ABS in five, and TPI in three cases.

Three sera (Cases 1, 2, and 3) were also tested 3, 6, and 9 months after antisyphilitic treatment. The FTA-ABS was reactive in one case only after 3 months but not subsequently; the FTA remained positive in all cases even after 9 months. All other tests gave negative results in all cases on all three occasions.

\section{(3) Complement-fixing reactivity of active serum fractions}

The first three fractions of gel-filtered control serum and of primary syphilitic serum were anticomplementary. When titres of complement fixation had been corrected with titres of anticomplementary activity, complement-fixing antibodies could not be demonstrated in the area of the $\mathrm{Ig} M$ peak.

The complement-fixing activity of the Ig G peak was distributed asymmetrically, as reagin was not found in Fractions 4 and 5 . RPC'FR antibodies showed the same localization in the TPI non-reactive serum fractions (Fig. 2).

One of the control sera (Control 1) contained complement-fixing antibodies in Fraction 7, though the whole serum did not.

Three months after specific treatment no complement-fixing antibodies were found.

\section{(4) TPI Reactivity of active serum fractions}

Fractions 6 to 8 of all six sera were reactive in the TPI test, although immobilizing antibody was demonstrable in only three whole sera (Fig. 3). In the majority of sera, it was located in the $\mathrm{Ig}$ G fraction; in two it was located in the Ig $M$ fraction. The asymmetrical distribution of reactivity in the area of the

TAB LE Serological findings before and after antisyphilitic treatment

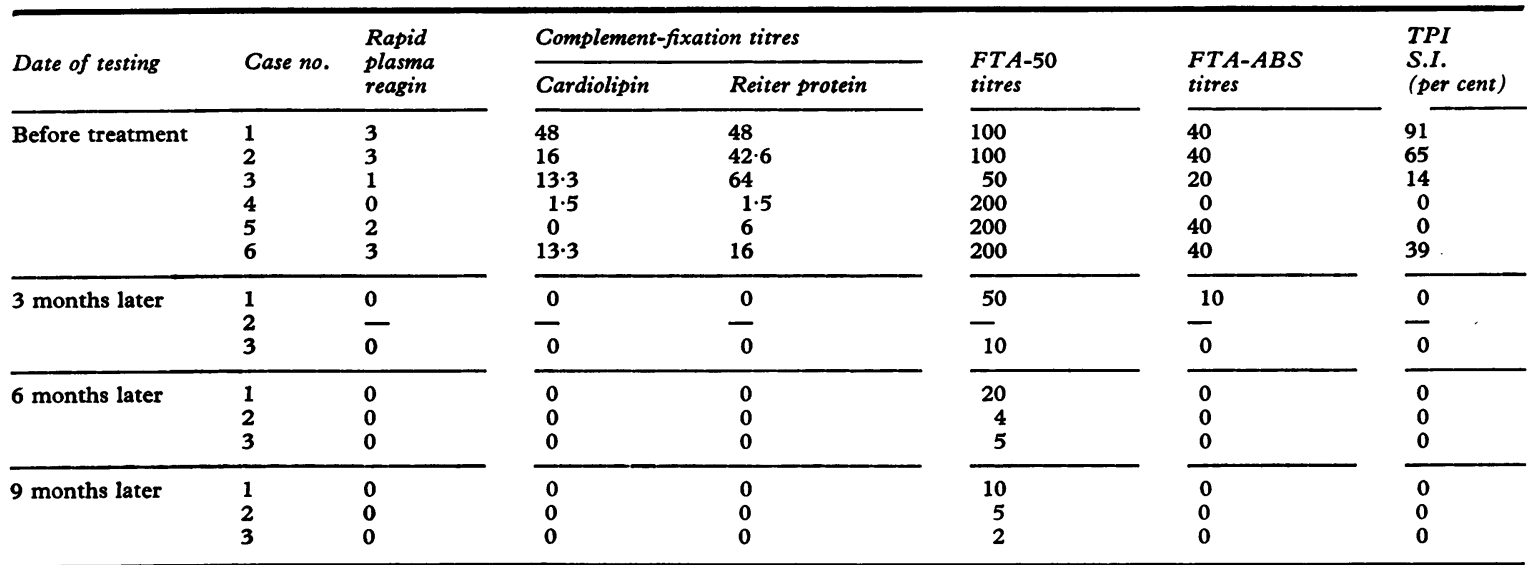



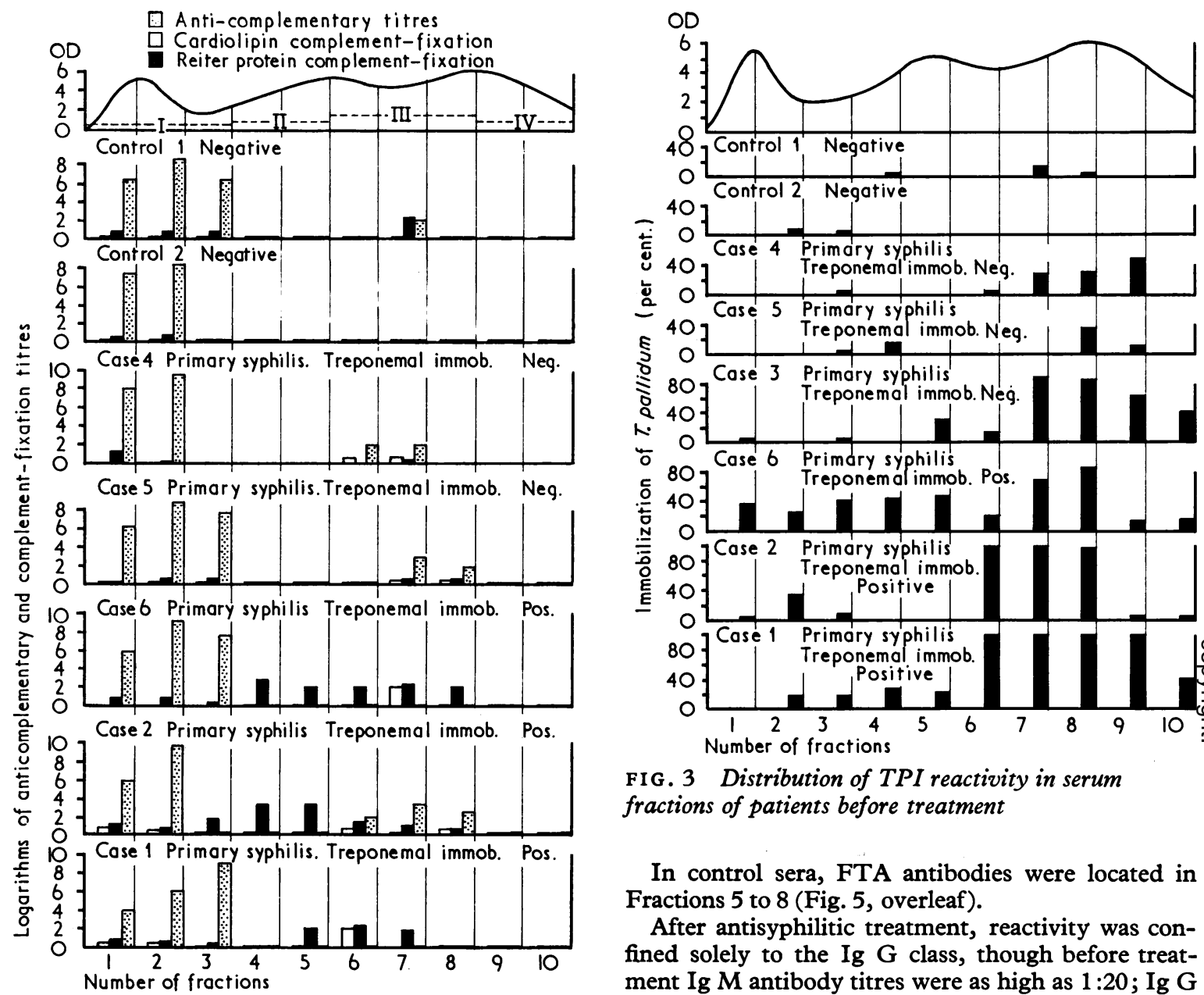

FI G. 3 Distribution of TPI reactivity in serum fractions of patients before treatment

In control sera, FTA antibodies were located in Fractions 5 to 8 (Fig. 5, overleaf).

After antisyphilitic treatment, reactivity was confined solely to the Ig G class, though before treatment Ig $M$ antibody titres were as high as $1: 20$; Ig G antibodies were demonstrable after 6 months and in one case, after 9 months (Fig. 6, overleaf).

The FTA-ABS reacted only with Fractions 4 and 5 in the serum of the untreated controls,

second peak was more conspicuous than in complement fixation tests (Fig. 3).

One of the controls (Control 1) showed a slight reactivity in Fractions 7 and 8.

Fractions 6 to 8 of all six sera remained reactive 3 months after antisyphilitic treatment, and two of them were reactive even after 6 months (Fig. 4, overleaf).

(5) FTA and FTA-ABS Reactivity of serum fractions FTA reactivity could be demonstrated in a broad area covering the first six fractions of gel-filtered serum. The ratio of the titres of $\mathrm{Ig} G$ and $\mathrm{Ig} M$ was $4: 1$, about the same in TPI reactive as in TPI nonreactive serum fractions. The distribution of antibodies was symmetrical in the area of the second peak.

(6) RPR Reactivity of serum fractions

Antibodies were not demonstrated in fractions of gelfiltered serum, probably because of their low antibody content and the low sensitivity of the test.

\section{Discussion}

In serum from cases of primary syphilis, reagin was found in both the slow and the fast gammaglobulins (Laurell, 1955; Laurell and Lindau, 1958; Portnoy and others, 1963) and in the Ig G and Ig M classes (Aho, 1967; Davis and others, 1945; Laurell and Malmquist, 1961).

In these experiments heat inactivation of fractions was omitted, so that the first peak was highly anti- 


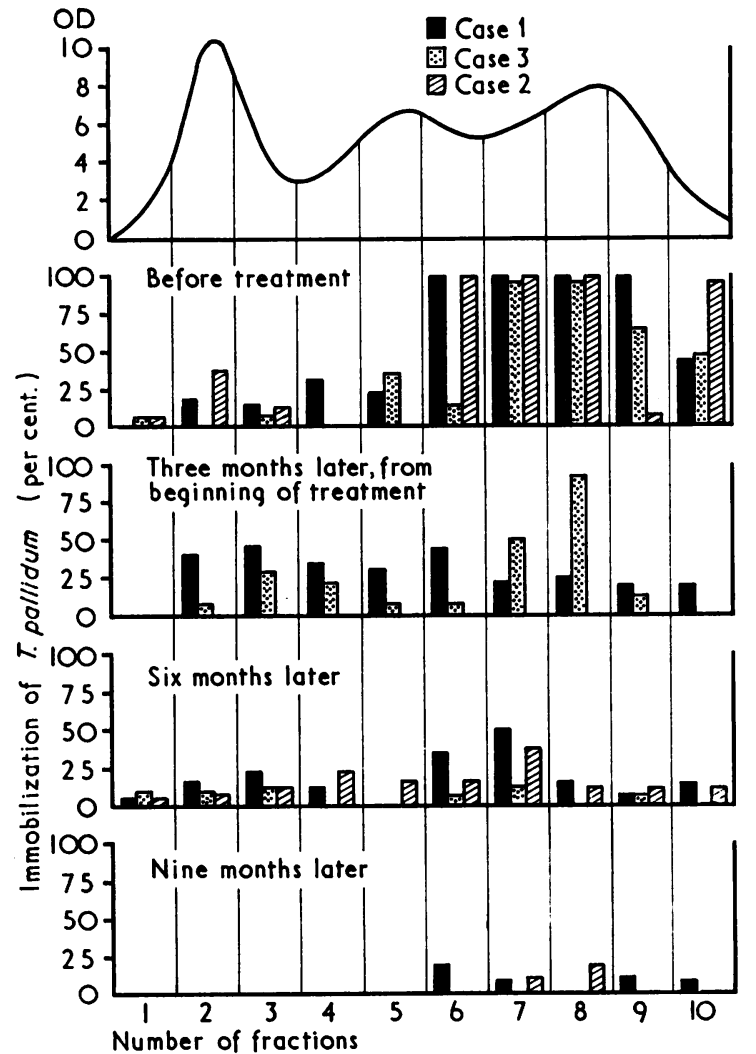

FIG. 4 Distribution of TPI reactivity in serum fractions before and after antisyphilitic treatment

complementary. Julian and others (1969) reported similar findings using the RPC'FR test. By subtracting the logarithmic titres of anticomplementary activity from the logarithmic titres of complement fixing reactivity, specific complement-fixing antibodies could not be demonstrated.

Fractions 4 and 5 were not reactive in the second peak, though this peak was found to consist mainly of Ig G, distributed symmetrically according to the immunoelectrophoretic patterns and the light absorbance of proteins. The asymmetrical distribution of antibodies, unlike the majority of the Ig G immunoglobulins, cannot be attributed to gel filtration separating the protein molecules according to their molecular size. One may postulate the presence of a factor in whole serum and in Fractions 4 and 5 which inhibits complement-fixation to the antigen-antibody complexes, but has no influence on its fixation to the red cell haemolysin system. Fraction 7 of one of the control sera was also reactive, though the whole serum was not. It seems that Wassermann antibodies may also occur normally in the serum of
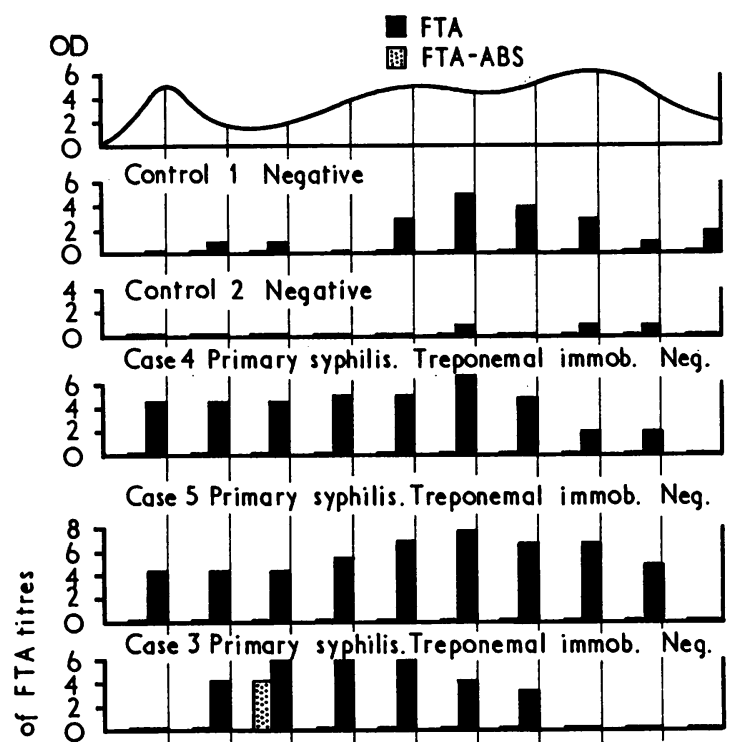

E 8 j Caseb Primary syphilis. Treponemal immob. Pos.

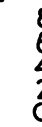

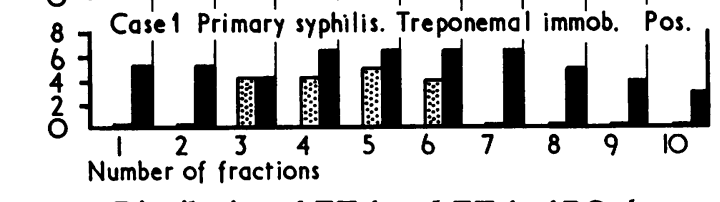

FIG. 5 Distribution of FTA and FTA-ABS titres in serum fractions

healthy subjects, but the presence of an unknown factor or factors inhibits their reactivity in whole serum.

The asymmetrical distribution of TPI reactivity was far more obvious than that of the C'FR. The fact that fractions of TPI non-reactive sera from cases of treated primary syphilis became reactive after gel filtration suggests the existence of an inhibitor which modifies the serological reactivity of the serum. The late appearance of TPI reactivity could be better explained by inhibition than by delayed immobilizing antibody formation.

In serum from cases of primary syphilis, immobilizing antibody has been shown to be localized in the slow gammaglobulin zone of the Ig G class by various authors (Julian and others, 1969; Laurell and Hederstedt, 1951; Portnoy and others, 1963). In two sera, it was also detected within the $\mathrm{Ig} M$ fraction, though its reactivity was low. 


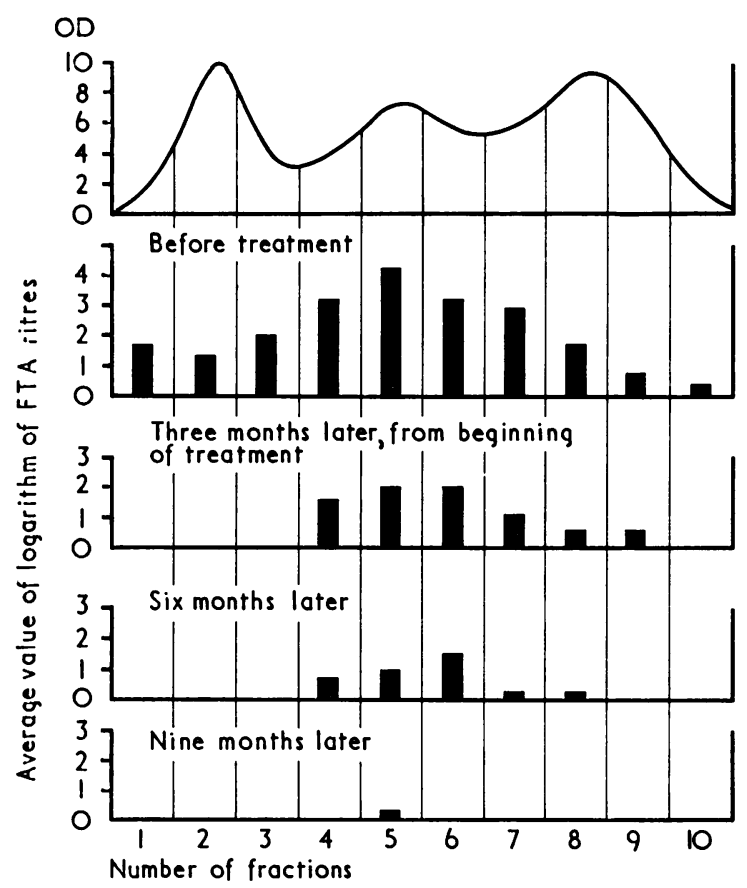

FIG. 6 Distribution of average values of FTA titres in serum fractions before and after antisyphilitic treatment

FTA antibodies were found equally in Ig G and Ig $M$, distributed symmetrically in the area of the second peak.

The ratio of the FTA reactivity of the $\mathrm{Ig} G$ and Ig $M$ classes was compared in TPI reactive and nonreactive sera, in order to obtain further evidence on the sequence of antibody formation in humans. TPI non-reactive sera had been thought to indicate shorter duration of infection, but the ratio of FTA reactivity according to immunoglobin class was the same in both groups of sera so that this supposition was discarded. A possible explanation is that primary syphilis, from the immunological point of view, is a more advanced situation (Julian and others, 1969). Furthermore, TPI reactivity may not assist the immunological distinction of various stages of syphilis, because the appearance of TPI positivity may depend not only on the level of antibodies but also on the inhibition of complement fixation to the antigen-antibody complexes. Such inhibition presumably varies individually, as no correlation could be found between STS results, FTA titres, and TPI reactivity.

After anti-syphilitic treatment, FTA antibodies could not be demonstrated within the Ig $M$ fractions, although titres were high before treatment.
It seems that the production of $\mathrm{Ig} M$ antibodies ceases before that of $\mathrm{Ig} \mathrm{G}$ antibodies.

\section{Summary}

The serological reactivity of active fractions of gelfiltered serum from cases of primary syphilis was investigated.

The first peak was anticomplementary. Reagin was found in the second part of the Ig G peak.

Treponemal immobilization reactivity showed similar location. Sera non-reactive in the TPI test before and after treatment immobilized $T$. pallidum after fractionation. It is supposed that a serum factor inhibited immobilization in whole sera and in the first part of the Ig $G$ peak.

FTA antibodies were located in a broad area covering the Ig G and Ig M immunoglobulin classes. Their ratio was essentially the same in sera reactive and non-reactive in the TPI test. No conclusion could be reached concerning the sequence of antibody formation.

Antibody production in the Ig $\mathrm{M}$ class of immunoglobulins ceased before that in the Ig G class.

\section{References}

Aно, K. (1967) Brit. F. vener. Dis., 43, 259

Davis, B. D., Moore, D. H., KabAT, E. A., and Harris, A. (1945) f. Immunol., 50, 1

Julian, A. J., Logan, L. C., and Norins, L. C. (1969) Ibid., 102, 1250

KIRÁLY, K. (1959) Börgyögy. vener. Szle, 35, 261

- (1968) Hautarzt, 19, 36

- and JoBbÁGY, A. (1969) Börgyögy. vener. Szle, 45, 1

,-- , and MECHER, T. (1965) Bull. Wld Hlth Org., 33, 687

- and Károlyi, I. (1956) Orv. Hetil., 97, 1.

and Kovats, L. (1967) Dermatologica (Basel), 135 443

LAURELL, A.-B. (1955) 'On antibodies separated by paper electrophoresis with special reference to the Wassermann reagins', Acta path. microbiol. scand., Suppl. 103

- and HEDERSTEDT, B. (1958) Ibid., 44, 88

- and LINDAU, A. (1958) Ibid., 42, 67

- and MALMQUist, J. (1961) Ibid., 51, 187

Portnoy, J., and Garson, W. (1960) Publ. Hlth Rep. (Wash.), 75, 985

- Julian, A. J., Smith, J. F., and Harris, A. (1963) Brit. F. vener. Dis., 39, 33

SCHEIDEGGER, J. J. (1955) Int. Arch. Allergy, 7, 103

Distribution des anticorps syphilitiques dans les fractions de sérum filtré en colonne

\section{SOMMAIRE}

La réactivité sérologique des fractions actives du sérum filtré en colonne fut étudiée dans la syphilis primaire. 
Le premier pic fut anticomplémentaire. $\mathrm{La}$ réagine fut trouvée dans la deuxième partie du pic IgG.

$\mathrm{La}$ fraction réactive pour l'immobilisation des tréponèmes fut trouvée au même siège. Les sérums négatifs à l'épreuve T.P.I., avant et après filtration, immobilisèrent le $T$. pallidum après fractionnement. On suppose qu'il existe un facteur sérique inhibant l'immobilisation dans les sérums entiers et dans la première partie du pic IgG.
Les anticorps intervenant dans le F.T.A. furent trouvés dans une large zone recouvrant les groupes des immuno-globulines IgG et IgM. Leur rapport fut dans l'ensemble le même pour les sérums positifs et pour les sérums négatifs au T.P.I. On ne peut aboutir à aucune conclusion concernant l'ordre de formation des anticorps.

La production d'anticorps dans le groupe IgM d'immuno-globulines cesse antérieurement à la production dans le groupe IgG. 